\title{
1 Role of astakine1 in regulating transglutaminase activity
}

2 Ratchanok Sirikharin*, Kingkamon Junkunlo, Kenneth Söderhäll and Irene Söderhäll

3 Department of Comparative Physiology, Uppsala University, Norbyvägen 18A, 75326, 4 Uppsala, Sweden

5 Corresponding author: Ratchanok Sirikharin, ratchanok.sirikharin@ebc.uu.se

\section{Abstract}

7 Transglutaminase (TGase) has been implicated in maintaining the undifferentiated stage of 8 hematopoietic stem cells (HSC) in the crayfish Pacifastacus leniusculus. TGase activity has 9 been reported to be regulated by astakine1, an essential crayfish cytokine for inducing new hemocyte synthesis in hematopoietic tissue (HPT). Here, the role of astakine1 in TGase activity regulation and clotting protein $(\mathrm{CP})$ cross-linking was characterized. A reduction in TGase activity was observed by the addition of purified astakine1 in vitro for both endogenous crayfish TGase and a commercial purified guinea pig liver TGase. As a result, we observed that astakinel inhibits TGase enzyme activity and acts as a non-competitive inhibitor for the TGase enzyme. Additionally, the clotting reaction was impaired in the presence of astakine1. A decrease in TGase-mediated crosslinking of $\varepsilon(\gamma$-glutamyl)-lysine bonds was also observed in the presence of astakine1. In conclusion, this study shows that astakine 1 acts as an inhibitor of TGase activity and that it also affects CP cross-linking during crayfish hematopoiesis.

Keywords: Transglutaminase activity; Astakine1; clotting protein; hematopoiesis 


\section{Introduction}

Invertebrates, including crustaceans, rely on innate immunity because they lack adaptive immunity. In crayfish, blood cells or hemocytes are important cellular mediators of immune reactions, such as phagocytosis and encapsulation, and they also contain immune components, such as the prophenoloxidase (proPO)-activating melanization cascade. (Cerenius et al., 2008; Jiravanichpaisal et al., 2006). Thus, the hemocyte number and its regulation are crucial for the animal to be able to defend itself. Hemocytes are produced and released into circulation, and this process is termed 'hematopoiesis'.

To study the molecules involved in hematopoiesis, using an in vitro culture system, the crayfish hematopoietic cytokine, astakine1, was identified (Söderhäll et al., 2005). Astakine1 was purified from plasma, and the plasma levels of astakine1 could be increased with LPS stimulation. Crayfish injected with a native purified astakinel had an increased total number of circulating hemocytes (Söderhäll et al., 2005), and astakine1 was shown to be essential to stimulate proliferation and differentiation of HPT cells, specifically in the semi-granular cell lineage (Lin et al., 2010). Astakinel can also reduce apoptosis in HPT cells by affecting the transcription of crustacean hematopoietic factor (CHF) in HPT cells (Lin et al., 2011). These studies all show that astakinel plays a regulating role at the crossroads between proliferation/differentiation and apoptosis.

Transglutaminase (TGase) is an abundant protein in the HPT cells of crayfish, and its activity has been determined in the hematopoietic tissue (Lin et al., 2008). TGase activity was low in HPT cells that were migrating out of the tissue in culture, in contrast to cells at the tissue center. This study suggested that TGase plays a role in maintaining the undifferentiated stage of HPT cells inside tissue (Lin et al., 2008). However, the role of astakine1 in TGase regulation is still unclear. High expression of clotting protein (CP) was found in crayfish HPT tissue in a transcriptome analysis (BioProject ID: PRJNA259594). CP is a well-known TGase substrate, in addition to collagen IV (Hall et al., 1999; Junkunlo et al., 2016). Crayfish CP is known to be involved in hemolymph clot formation (Wang et al., 2001). In osteoblast cell cultures, TGase activity was reported to be essential for the initial formation of the fibronectin-collagen network, which subsequently affected cell differentiation and mineralization in MC3T3-E1 osteoblast cultures (Al-Jallad et al., 2006). TGase activity is important for extracellular matrix (ECM) stabilization, and a decrease in its extracellular activity causes hemocyte release from HPT (Lin et al., 2008). 
This study aimed to i) identify the role of astakine1 in regulating TGase activity and ii) show how astakine1 regulation of TGase activity affects the clotting process.

\section{Materials and Methods}

62

63

64

65

66

67

68

69

70

71

72

80

2.1. Experimental animals

Freshwater crayfish ( $P$. leniusculus) were obtained from Lake Erken (Sweden). Intermolt and healthy crayfish were maintained in aerated aquaria at $10{ }^{\circ} \mathrm{C}$ and used for the experiments.

\subsection{Astakine1 purification from plasma}

Hemolymph was collected from 15-20 crayfish and then centrifuged at 3,000 $\times g$ for 5 min to spin down the hemocytes, and the cell-free plasma supernatant was collected. The pooled plasma supernatant was diluted with $20 \mathrm{mM}$ Hepes and $150 \mathrm{mM} \mathrm{NaCl}(\mathrm{V}: \mathrm{V}=1: 1)$ and then supplemented with trifluoroacetic acid (TFA, Merck) to a final concentration of $0.5 \%$. The diluted plasma was centrifuged at $8,000 \times g$ for $20 \mathrm{~min}$ at $4^{\circ} \mathrm{C}$ to remove precipitate, followed by filtration through a $0.45 \mu \mathrm{m}$ filter. The resulting plasma was subjected to a small single-use sep-pak C18 cartridge (Waters) pre-equilibrated with 100\% acetonitrile, followed by $20 \mathrm{ml}$ of wash buffer ( $10 \mathrm{mM}$ Hepes, $150 \mathrm{mM} \mathrm{NaCl}$, and $0.5 \%$ TFA). The plasma was passed through the sep-pak column twice and washed with $50 \mathrm{ml}$ wash buffer. Bound proteins were eluted stepwise with wash buffer containing $10 \%-100 \%$ acetonitrile. The $50 \%$ acetonitrile eluted fractions were aliquoted and vacuum-dried. The dried pellet was stored at $-80{ }^{\circ} \mathrm{C}$ and suspended with L-15 medium before use.

\subsection{Transglutaminase enzyme preparation}

To prepare endogenous TGase, HPT cells were freshly isolated, as described previously (Lin et al., 2008). The cells were then homogenized in $100 \mu$ RIPA buffer (50 mM Tris, $150 \mathrm{mM} \mathrm{NaCl}, 10 \mathrm{mM}$ EDTA, 1\% IGEPAL, 1\% SDS, pH 7.5) containing $1 \mathrm{X}$ protease inhibitor cocktail (Roche). After centrifugation of the homogenate at $13,000 \times \mathrm{g}$ for $15 \mathrm{~min}$ at $4^{\circ} \mathrm{C}$, the protein supernatant was immediately used in a TGase inhibition assay. The protein concentration was determined by using Coomassie Plus protein assay reagent (Thermo Scientific). 
2.4. Guinea pig liver TGase

Lyophilized Guinea pig liver TGase (T5398) powder was purchased from Sigma and

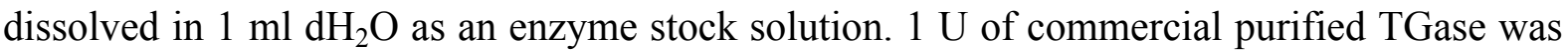
freshly prepared before use in the experiments.

\subsection{Transglutaminase activity assay}

The TGase activity was assayed by using a modified non-radioactive microtiter plate (Slaughter et al., 1992). Briefly, the microtiter plate was coated with $100 \mu$ of N,N'dimethylcasein (Sigma, $10 \mathrm{mg} / \mathrm{ml}$ ) at $4^{\circ} \mathrm{C}$ overnight. After blocking with blocking solution $(0.5 \%$ BSA in $0.1 \mathrm{M}$ Tris- $\mathrm{HCl}, \mathrm{pH} 8.5)$ for $30 \mathrm{~min}$ at room temperature, the wells were washed three times with $0.1 \mathrm{M}$ Tris- $\mathrm{HCl}, \mathrm{pH}$ 8.5. The incubation mixture, which contained $5 \mathrm{mM} \mathrm{CaCl}_{2}, 10 \mathrm{mM}$ dithiothreitol, $0.1 \mathrm{mM}$ of 5-(biotinamido) pentylamine substrate, $10 \mu \mathrm{g}$ of whole cell lysates and $0.1 \mathrm{M}$ Tris- $\mathrm{HCl}, \mathrm{pH} 8.5$, was added to obtain a total volume of $200 \mu \mathrm{l}$ per well. After incubation at $37^{\circ} \mathrm{C}$ for $30 \mathrm{~min}$, the reaction was stopped by washing twice with $200 \mathrm{mM}$ EDTA, followed by washing three times with $0.1 \mathrm{M}$ Tris-HCl, $\mathrm{pH}$ 8.5. Streptavidin-horseradish peroxidase conjugate (GE Healthcare) was diluted to 1:1,000 in blocking solution before it was added to the wells for a $1 \mathrm{~h}$ incubation at room temperature. The plate was washed once with $0.01 \%$ Triton $\mathrm{X}-100$, followed by five washes with $0.1 \mathrm{M}$ Tris-HCl, $\mathrm{pH}$ 8.5. Then, $50 \mu \mathrm{l}$ of 3,3',5,5'-Tetramethylbenzidine substrate solution (TMB, Sigma) was added to each well. After incubation for $10 \mathrm{~min}$ at room temperature, the reactions were stopped by the addition of $50 \mu \mathrm{l}$ of $3 \mathrm{~N} \mathrm{HCl}$ to each well. The TGase cross-linking activity in which 5'-(biotinamido) pentylamine was incorporated into N,N'dimethylcasein was quantified by measuring the absorbance at $450 \mathrm{~nm}$ in a plate reader (Molecular Device).

To examine the temperature dependence of the endogenous crayfish TGase enzyme, samples of whole cell lysate $(10 \mu \mathrm{g} /$ well $)$ were tested at different temperatures, including $4,16,25$ and $37^{\circ} \mathrm{C}$.

\subsection{Transglutaminase inhibition assay}

All kinetic and inhibition experiments were performed by using a modified non-radioactive microtiter plate, as described above. The reaction mixture consisted of four concentrations of 5-(biotinamido) pentylamine substrate $(0.012,0.025,0.05$ and $0.1 \mathrm{mM})$ in 
the presence of a fixed amount of commercial Guinea pig TGase (dilution 1:1,000 in $0.1 \mathrm{M}$ Tris- $\mathrm{HCl}, \mathrm{pH} 8.5)$ and three different concentrations of purified native astakine1 (0.2, 0.4 and $0.6 \mu \mathrm{M})$. The optical density is expressed as specific enzyme activity and plotted against the molar ratio of astakine1.

\subsection{Purification of clotting protein (CP) from crayfish plasma}

Crayfish hemolymph from 9 crayfish (approximately $15 \mathrm{ml}$ ) was removed and placed into $15 \mathrm{ml}$ ice-cold anti-coagulant buffer $(0.14 \mathrm{M} \mathrm{NaCl}, 0.1 \mathrm{M}$ glucose, $30 \mathrm{mM}$ trisodium citrate, $26 \mathrm{mM}$ citric acid, pH 4.6) (Kopáček et al., 1993). The hemocyte pellets were removed by centrifugation at $800 \times g, 10 \mathrm{~min}$ at $4{ }^{\circ} \mathrm{C}$. Then, the plasma was further dialyzed (Spectra/Por, 6-8 MWCO) towards $10 \mathrm{mM}$ sodium phosphate $\mathrm{pH} 6.0$ containing $1 \mathrm{mM}$ EDTA overnight at $4{ }^{\circ} \mathrm{C}$. After centrifugation of the dialyzed plasma at $2,500 \times \mathrm{g}, 10 \mathrm{~min}$ at $4{ }^{\circ} \mathrm{C}$, the precipitated orange colored CP pellets were obtained and re-suspended in $500 \mu \mathrm{l}$ $0.2 \mathrm{M}$ sodium phosphate, $\mathrm{pH} 6.0$, containing $1 \mathrm{mM}$ EDTA. The resulting supernatant was collected as CP-depleted plasma and used as a control in the clotting assay. The purity of clotting protein was analyzed by $7.5 \%$ SDS-PAGE and compared with CP-depleted plasma and crayfish plasma.

\subsection{The clotting assay}

Crayfish plasma $(10 \mathrm{mg} / \mathrm{ml})$, CP-depleted plasma $(10 \mathrm{mg} / \mathrm{ml})$, and purified CP $(10 \mathrm{mg} / \mathrm{ml})$ samples were dialyzed separately overnight against buffer A $(50 \mathrm{mM}$ Tris- $\mathrm{HCl}$, $0.15 \mathrm{M} \mathrm{NaCl}, \mathrm{pH}$ 8.0). The clotting assay was tested in tubes with or without astakine1 $(0.6 \mu \mathrm{M})$. Plasma for re-suspending astakine1 was used as a control sample. Five different samples were mixed as follows: (1) $20 \mu \mathrm{CP}+390 \mu \mathrm{l}$ buffer A $+25 \mu 1$ plasma; (2) $400 \mu 1$ CP-depleted plasma $+10 \mu \mathrm{l}$ buffer A $+25 \mu \mathrm{l}$ plasma; (3) $20 \mu \mathrm{l} \mathrm{CP}+390 \mu \mathrm{l}$ buffer A $+25 \mu \mathrm{l}$ $0.6 \mu \mathrm{M}$ astakine1; (4) $400 \mu \mathrm{l} \mathrm{CP-depleted} \mathrm{plasma}+10 \mu \mathrm{l}$ buffer $\mathrm{A}+25 \mu \mathrm{l} 0.6 \mu \mathrm{M}$ astakine1 and (5) $400 \mu \mathrm{l}$ crayfish plasma $+10 \mu \mathrm{l}$ buffer $\mathrm{A}+25 \mu \mathrm{l}$ plasma. All test tube samples received aliquots of $50 \mu \mathrm{l}$ of $1 \mathrm{U}$ commercial TGase and $15 \mu \mathrm{l}$ of $1 \mathrm{M} \mathrm{CaCl}_{2}$. After incubation for $3 \mathrm{~h}$ at room temperature, the tubes were tilted and laid down observe clot formation. 


\subsection{TGase-mediated crosslinking assay}

The experiments were performed based on CP polymerization, as reported previously (Kopáček et al., 1993). Briefly, $5 \mu \mathrm{l}$ of purified CP $(2 \mu \mathrm{g} / \mu \mathrm{l})$ was tested in the presence or absence of astakinel $(0.6 \mu \mathrm{M})$. CP-depleted plasma samples $(2 \mu \mathrm{g} / \mu \mathrm{l})$ were used as controls. Five microliters of $1 \mathrm{U}$ commercial purified TGase and $5 \mu \mathrm{l}$ of $0.12 \mathrm{M} \mathrm{CaCl}_{2}$ were added to each tube. After incubation at $37^{\circ} \mathrm{C}$ for $3 \mathrm{~h}$, the reaction was terminated with $1 \mu \mathrm{l}$ of $0.2 \mathrm{M}$ EDTA, followed by western blotting. The different samples were mixed with protein loading buffer (Laemmli sample buffer, $62.5 \mathrm{mM}$ Tris-HCl, 2\% SDS, 10\% (v/v) glycerol, $0.1 \mathrm{M}$ DTT and $0.01 \%$ bromophenol blue, $\mathrm{pH}$ 6.8), separated using 7\% SDS-PAGE and then electrotransferred onto a polyvinylidene fluoride membrane (PVDF) (GE Healthcare) for $2 \mathrm{~h}$. The blot was blocked in 10\% skim milk blocking buffer in PBS-T $(0.5 \%$ tween-20 in $1 \times$ PBS buffer, $\mathrm{pH}$ 7.4) for $1 \mathrm{~h}$ at room temperature. The membrane was incubated with anti- $\varepsilon(\gamma-$ glutamyl)-lysine monoclonal antibody at a 1:500 dilution (ab424, Abcam) in blocking buffer at $4{ }^{\circ} \mathrm{C}$ overnight. After extensive washing, the membrane was incubated with anti-mouse antibody conjugated with horseradish peroxidase (GE Healthcare) at a 1:1,000 dilution. The signal detection was performed by using Clarity western ECL substrate (Bio-Rad) according to the manufacturer's instructions.

\section{Results}

\subsection{Astakine1 inhibits TGase enzymatic activity}

To determine the effect of astakine1 on TGase-mediated crosslinking activity, purified native astakine1 from crayfish plasma was added to a TGase activity assay reaction mixture. This was investigated by using a modified non-radioactive microtiter plate test to show if purified astakine1 could compete with TGase-mediated 5-(biotinamido)-pentylamine $\left(\mathrm{BPHN}_{2}\right)$ incorporation. $\mathrm{BPNH}_{2}$ is a conjugated biotin primary amine, which is covalently incorporated into N,N'-dimethylcasein by TGase enzyme activity. To better understand the role of astakine1 in TGase activity regulation, a purified commercial Guinea pig liver TGase was also used for comparison with the crayfish TGase. Regarding the temperature dependence of the endogenous TGase, we found that there was no significant difference in the TGase activities at 16,25 and $37^{\circ} \mathrm{C}$ (Fig. 1). There was significant activity at $4{ }^{\circ} \mathrm{C}$. Then, TGase activity inhibition was further tested at $37{ }^{\circ} \mathrm{C}$ with different concentrations of astakine1 (from 0.2 to $0.6 \mu \mathrm{M}$ ) for native endogenous and commercial TGase. The results 
show that by increasing the astakinel concentration, the TGase enzyme activity was decreased (Fig. 2). The highest astakinel concentration, $0.6 \mu \mathrm{M}$, resulted in a remaining activity of $24 \%$ for the endogenous TGase compared with the control (Fig. 2A). The same astakine1 concentration was reduced to a residual activity of $50 \%$ for the commercial TGase enzyme when compared with the control (Fig. 2B). This result shows that astakine1 inhibited the TGase mediated-crosslinking reaction.

\subsection{Astakinel acts as a non-competitive inhibitor for TGase activity}

To investigate the kinetics of the inhibition experiments, commercial TGase and varying concentrations of the substrate and astakine 1 were evaluated. The obtained data were analyzed by using GraphPad Prism with non-linear regression analysis, and a MichaelisMenten kinetics graph was constructed (Fig. 3). We found that astakinel seemed to act as a non-competitive inhibitor, as the inhibition was not decreased when the substrate concentration was increased.

\subsection{Reduced clotting reaction activity by astakine1}

To test whether TGase activity inhibition by astakine1 could affect the clotting reaction, the ability for TGase to catalyze CP cross-linking in a gel formation assay was evaluated. The clotting reaction was supplemented with commercial $\mathrm{TGase}$ and $\mathrm{Ca}^{2+}$ in the mixture. The clotting ability is shown in Table 1 . The non-dialyzed plasma samples provided the most obvious clot formation. The purified CP showed a nearly identical clotting ability as that of the plasma, while the CP-depleted plasma had low or no clot formation. However, the clotting ability of the purified CP was clearly reduced when supplemented with astakine1 (Table 1). This result indicates that astakine1 can also interfere with TGase-mediated CP crosslinking.

\subsection{Astakine1 affects TGase-mediated crosslinking activity}

In crayfish, it is known that CP can be used by TGase enzymes for cross-linking during hemolymph gel formation (Kopáček et al., 1993; Hall et al., 1999). CP is highly expressed in HPT tissue, and therefore, we intended to clarify whether impaired-TGase activity could impact $\mathrm{CP}$ crosslinking by including astakinel in the reaction. We tested if astakine 1 could inhibit the TGase enzyme crosslinking activity by incubation of purified CP with or without astakine1 in the presence of commercial TGase and $\mathrm{Ca}^{2+}$. CP-depleted 
plasma was used as a negative control. Western blot analysis revealed a high molecular weight signal $(>250 \mathrm{kDa})$ in the sample with purified CP without astakine1, while this band was not detected in the CP-depleted plasma (Fig. 4). A low amount of cross-linking at the high molecular weight $(>250 \mathrm{kDa})$ was observed in the purified CP sample when astakine1 was added. This suggests that astakine1 can inhibit the TGase-mediated crosslinking reaction (Fig. 4).

\section{Discussion}

The production and renewal of hemocytes occur in the hematopoietic tissue, and this process is tightly regulated to control and balance hemocyte numbers in the circulatory system. Astakinel and TGase have been determined as important factors in blood cell differentiation/proliferation in freshwater crayfish (Lin et al., 2008; Söderhäll et al., 2005). Astakinel is a homologue of vertebrate prokineticins, endocrine gland-derived vascular endothelial growth factor (EG-VEGF)/PK1 and Bv8/PK2. They are involved in several physiological functions, such as angiogenesis, neurogenesis and circadian rhythms (Monnier and Samson, 2008; Negri et al., 2007). Vertebrate prokineticins are known to be involved in hematopoiesis by promoting differentiation and mobilization of granulocyte and monocyte lineage cells (Dorsch et al., 2005; LeCouter et al., 2004). In crayfish, astakine1 is known as a hematopoietic growth factor, and it especially stimulates the differentiation of the SGC hemocyte lineage (Lin et al., 2010). Crayfish TGase from hemocytes catalyzes the clotting process, which depends on the TGase-mediated crosslinking of plasma CP (Kopáček et al., 1993). However, a function of TGase in HPT tissue has been shown where it stabilizes the matrix and maintains HPT cells in an undifferentiated stage (Lin et al., 2008). Here, we show a function of astakine1 in TGase activity regulation in vitro. We show that astakine1 can inhibit TGase activity in a dose-dependent manner. Endogenous TGase is a crude enzyme source that is prepared from HPT lysate, which means that others proteins were present in the inhibition assay reaction. However, it is important to note that TGase is very abundant in HPT cells and accounts for $40-50 \%$ of the total protein concentration (Lin et al., 2008). Astakinel seems to act as a non-competitive inhibitor of TGase activity (Fig. 3). Interestingly, endogenous TGase functioned over a wide range of temperatures. The freshwater crayfish $P$. leniusculus normally lives in a wide range of habitats but generally prefers cold water. Therefore, the observation that the optimum temperature for TGase has a 
very broad range, from $16{ }^{\circ} \mathrm{C}$ to $37{ }^{\circ} \mathrm{C}$, and that it was still active at $4{ }^{\circ} \mathrm{C}$ may be a possible adaptation of the cold-blooded animal.

In shrimp, TGase and crustin have been reported as RNA-binding proteins to the 3'-UTR of astakine, and a reduction of TGase and crustin by siRNA increased the protein 243 level of astakine, while the astakine mRNA level remained unchanged (Chang et al., 2013).

244 In this study, we showed that astakine1 regulates TGase at the protein level by inhibiting TGase activity. Additionally, after prolonged culture of HPT cells with plasma containing astakine1, the extracellular TGase activity was decreased. When the TGase mRNA expression was decreased with dsRNAi, the HPT cells started to intensely spread (Lin et al., 2008). This indicates that extracellular TGase is involved in extracellular matrix (ECM) interactions in order to maintain the HPT tissue microenvironment and to suppress stem cell differentiation. TGase is well known for playing a role in ECM protein crosslinking (Belkin, 2011), and TGase activity is crucial for cellular matrix stabilization and cell differentiation/proliferation ( $\mathrm{Li}$ et al., 2015; Myneni et al., 2014). Type IV collagen has been characterized as an ECM protein in crayfish, and it was found to be co-localized with TGase on the surface of HPT cells (Junkunlo et al., 2016). Interestingly, CP mRNA expression is high in HPT, and therefore, it is likely that CP could be an ECM protein in HPT tissue. Moreover, the CP subunits contain both glutamine and lysine residues that are available for crosslinking by TGase (Hall et al., 1999). To reveal how astakine1 regulates TGase and CP and their clotting formation, we first observed the clotting reactions with purified $\mathrm{CP}$ and TGase with or without astakine1. The results showed that astakine1 decreased clot formation in the presence of purified CP and TGase. Additionally, we also confirmed the TGasemediated crosslinking reaction and $\mathrm{CP}$ polymerization by determining the $\varepsilon(\gamma$-glutamyl)lysine bond level. The result showed a stronger crosslinking bond signal in the purified CP when astakine 1 was deprived, while purified $\mathrm{CP}$ that included astakine 1 showed lower signal levels in the western blot results. This clearly indicates a role for $\mathrm{CP}$ in hematopoiesis. That astakine 1 is affecting clot formation by inhibiting TGase enzyme activity and not only induce a higher hemocyte synthesis is logic since clot formation during wound healing should be a highly localized response. During wounding hemocytes are attracted to the wound site to release TGase enzyme and after some clotting has occurred at the wound site this process must be stopped to avoid a total clot formation in the hemolymph. This process is similar to that occurring with control of melanization, where the activating protease is rapidly degraded to avoid unwanted melanization. In addition, there are inhibitors in plasma such as pacifastin 
272 to inhibit the activating protease and if phenoloxidase is still active the melanization 273 inhibiting protein (MIP9) will also aid in control of melanization so it only occurs locally 274 (Aspán et al., 1990; Liang et al., 1997; Söderhäll et al., 2009).

\section{Conclusion}

In summary, the function of astakine1 in regulating TGase activity was studied. Astakine1 could inhibit crayfish and rodent TGase enzymatic crosslinking activity. Moreover, we showed that astakine1 seems to act as a non-competitive inhibitor. The inhibitory activity of astakine 1 also led to impaired TGase-mediated crosslinking of the purified clotting protein.

\section{Acknowledgement}

This work was supported by the Swedish Research Council (VR 621-2012-2418) to KS.

Figure Legends

Fig. 1. TGase activity in HPT cell lysates at different temperatures. The amount of TGasemediated incorporation of 5 '-(biotinamido) pentylamine $\left(\mathrm{BPNH}_{2}\right)$ was measured at an absorbance of $450 \mathrm{~nm}$. The columns represent the mean of three independent experiments, and the error bars represent SD values. Student's t-test $p$ values are labeled above the column.

Fig. 2. TGase activity inhibition in HPT cell lysate by purified astakine1 (A) and inhibition of Guinea pig liver TGase by purified astakine1 (B). The columns represent the mean of independent experiments, which include HPT cells lysate $(\mathrm{n}=5)$ and Guinea pig liver TGase $(n=3)$. The error bars represent SD values. Significant differences are indicated by the following asterisks: ${ }^{*}, p<0.05 ; * * *, p<0.001$.

Fig. 3. Various concentrations of astakine1 inhibit TGase activity: $0(\bullet), 0.2(\square), 0.4(\mathbf{\Delta})$, and $0.6(\mathrm{O}) \mu \mathrm{M}$, with different $\mathrm{BPNH}_{2}$ concentrations $(0$ to $0.1 \mathrm{mM})$, are shown following a solid-phase microtiter plate assay.

Fig. 4. A TGase activity assay shows $\varepsilon(\gamma$-glutamyl)-lysine bond formation by TGasemediated CP cross-linking. Western blot results are shown with an anti- $\varepsilon$ ( $\gamma$-glutamyl)-lysine monoclonal antibody at a 1:500 dilution (Abcam). This experiment was repeated three times with similar results. 


\section{References}

Al-Jallad, H.F., Nakano, Y., Chen, J.L., McMillan, E., Lefebvre, C., Kaartinen, M.T., 2006. Transglutaminase activity regulates osteoblast differentiation and matrix mineralization in MC3T3-E1 osteoblast cultures. Matrix. Biol. 25, 135-148.

Aspán, A., Hall, M., Söderhäll, K., 1990. The effect of endogeneous proteiase inhibitors on the prophenoloxidase activating enzymes, a serine proteinase from crayfish hemocytes. Insect Biochem 20, 485-492.

Belkin, A.M., 2011. Extracellular TG2: emerging functions and regulation. FEBS J 278, 4704-4716.

Cerenius, L., Lee, B.L., Söderhäll, K., 2008. The proPO-system: pros and cons for its role in invertebrate immunity. Trends Immunol. 29, 263-271.

Chang, Y.T., Lin, C.Y., Tsai, C.Y., Siva, V.S., Chu, C.Y., Tsai, H.J., Song, Y.L., 2013. The new face of the old molecules: crustin Pm4 and transglutaminase type I serving as rnps down-regulate astakine-mediated hematopoiesis. PLoS One 8, e72793.

Cui, C., Wang, S., Myneni, V.D., Hitomi, K., Kaartinen, M.T., 2014. Transglutaminase activity arising from Factor XIIIA is required for stabilization and conversion of plasma fibronectin into matrix in osteoblast cultures. Bone 59, 127-138.

Dorsch, M., Qiu, Y., Soler, D., Frank, N., Duong, T., Goodearl, A., O'Neil, S., Lora, J., Fraser, C.C., 2005. PK1/EG-VEGF induces monocyte differentiation and activation. J Leukoc. Biol. 78, 426-434.

Hall, M., Wang, R., van Antwerpen, R., Sottrup-Jensen, L., Söderhäll, K., 1999. The crayfish plasma clotting protein: a vitellogenin-related protein responsible for clot formation in crustacean blood. Proc. Natl. Acad. Sci. U S A 96, 1965-1970.

Jiravanichpaisal, P., Lee, B.L., Söderhäll, K., 2006. Cell-mediated immunity in arthropods: hematopoiesis, coagulation, melanization and opsonization. Immunobiology 211, 213-236.

Junkunlo, K., Söderhäll, K., Söderhäll, I., Noonin, C., 2016. Reactive oxygen species affects transglutaminase activity and regulates hematopoiesis in a crustacean. J. Biol. Chem. 291, 17593-17601.

Kopáček, P., Hall, M., Söderhäll, K., 1993. Characterization of a clotting protein, isolated from plasma of the freshwater crayfish Pacifastacus leniusculus. Eur. J. Biochem. 213, 591-597. 
LeCouter, J., Zlot, C., Tejada, M., Peale, F., Ferrara, N., 2004. Bv8 and endocrine glandderived vascular endothelial growth factor stimulate hematopoiesis and hematopoietic cell mobilization. Proc. Natl. Acad. Sci. U S A 101, 16813-16818.

Li, B., Tian, X.B., Hu, R.Y., Xu, F.B., Zhao, J.M., 2015. Mechanism of BMP and TG2 in mesenchymal stem cell osteogenesis. Eur. Rev. Med. Pharmacol. Sci. 19, 4214-4219.

Liang, Z., Sottrup-Jensen, L., Aspán, A., Hall, M., Söderhäll, K., 1997. Pacifastin, a novel $155-\mathrm{kDa}$ heterodimeric proteinase inhibitor containing a unique transferrin chain. Proc Natl Acad Sci U S A 94, 6682-6687.

Lin, X., Novotny, M., Söderhäll, K., Söderhäll, I., 2010. Ancient cytokines, the role of astakines as hematopoietic growth factors. J. Biol. Chem. 285, 28577-28586.

Lin, X., Söderhäll, K., Söderhäll, I., 2008. Transglutaminase activity in the hematopoietic tissue of a crustacean, Pacifastacus leniusculus, importance in hemocyte homeostasis. BMC Immunol. 9, 58.

Lin, X., Söderhäll, K., Söderhäll, I., 2011. Invertebrate hematopoiesis: an astakine-dependent novel hematopoietic factor. J. Immunol. 186, 2073-2079.

Monnier, J., Samson, M., 2008. Cytokine properties of prokineticins. FEBS J 275, 40144021.

Myneni, V.D., Hitomi, K., Kaartinen, M.T., 2014. Factor XIII-A transglutaminase acts as a switch between preadipocyte proliferation and differentiation. Blood 124, 1344-1353.

Negri, L., Lattanzi, R., Giannini, E., Melchiorri, P., 2007. Bv8/Prokineticin proteins and their receptors. Life Sci. 81, 1103-1116.

Noonin, C., Lin, X., Jiravanichpaisal, P., Söderhäll, K., Söderhäll, I., 2012. Invertebrate hematopoiesis: an anterior proliferation center as a link between the hematopoietic tissue and the brain. Stem Cells Dev. 21, 3173-3186.

Slaughter, T.F., Achyuthan, K.E., Lai, T.S., Greenberg, C.S., 1992. A microtiter plate transglutaminase assay utilizing 5-(biotinamido)pentylamine as substrate. Anal. Biochem. 205, 166-171.

Söderhäll, I., Kim, Y.A., Jiravanichpaisal, P., Lee, S.Y., Söderhäll, K., 2005. An ancient role for a prokineticin domain in invertebrate hematopoiesis. J. Immunol. 174, 6153-6160.

Söderhäll, I., Wu, C., Novotny, M., Lee, B.L., Söderhäll, K., 2009. A Novel Protein Acts as a Negative Regulator of Prophenoloxidase Activation and Melanization in the Freshwater Crayfish Pacifastacus leniusculus. J. Biol. Chem. 284, 6301-6310. 
369 Table 1 Clotting formation of purified clotting protein in the presence or absence astakine1. Semi-quantitative determination where ++++ means a complete clot formation and 0 means

Wang, R., Liang, Z., Hal, M., Söderhäll, K., 2001. A transglutaminase involved in the coagulation system of the freshwater crayfish, Pacifastacus leniusculus. Tissue localisation and cDNA cloning. Fish Shellfish Immunol. 11, 623-637. low or no clot formation. A representative picture from one of four experiments is included.

\begin{tabular}{llll}
\hline Sample & Clotting \\
\hline $\mathrm{CP}+\mathrm{TGase}+\mathrm{Ca}^{2+}$ & & \\
$\mathrm{CP}$-depleted plasma $+\mathrm{TGase}^{2+} \mathrm{Ca}^{2+}$ & & \\
$\mathrm{CP}+\mathrm{TGase}+$ astakine1 $+\mathrm{Ca}^{2+}$ & & \\
\hline
\end{tabular}




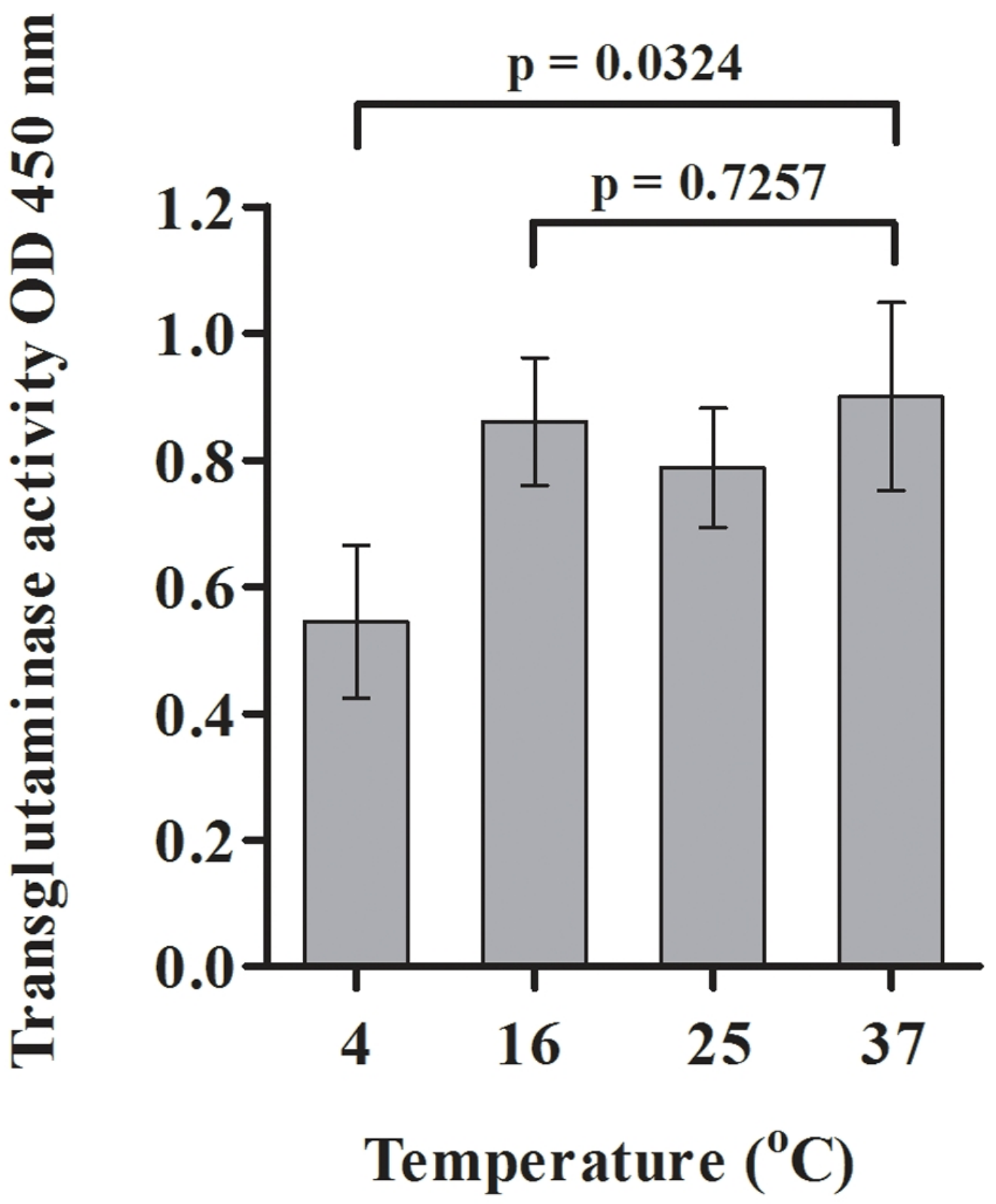


(A)

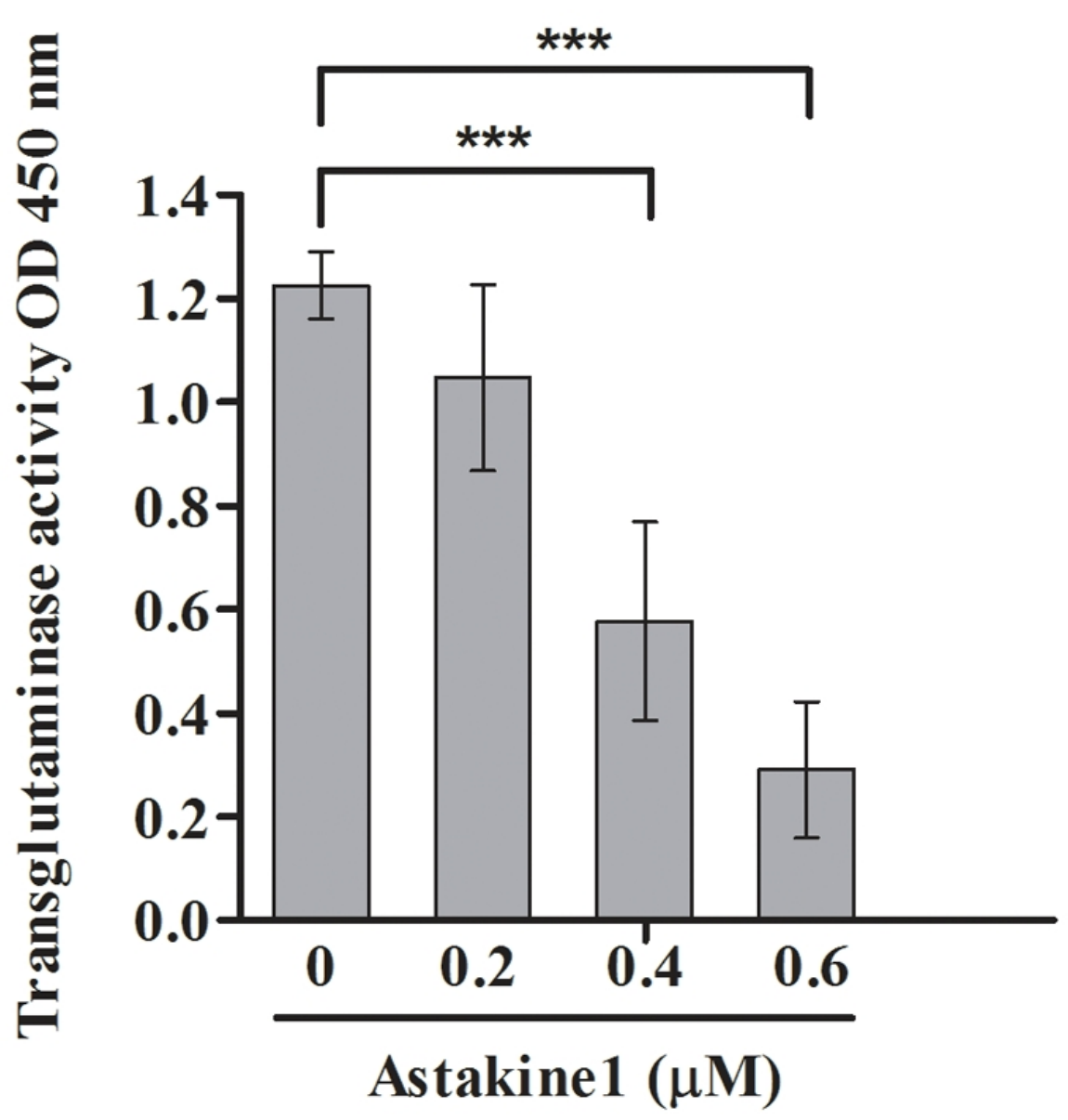

(B)

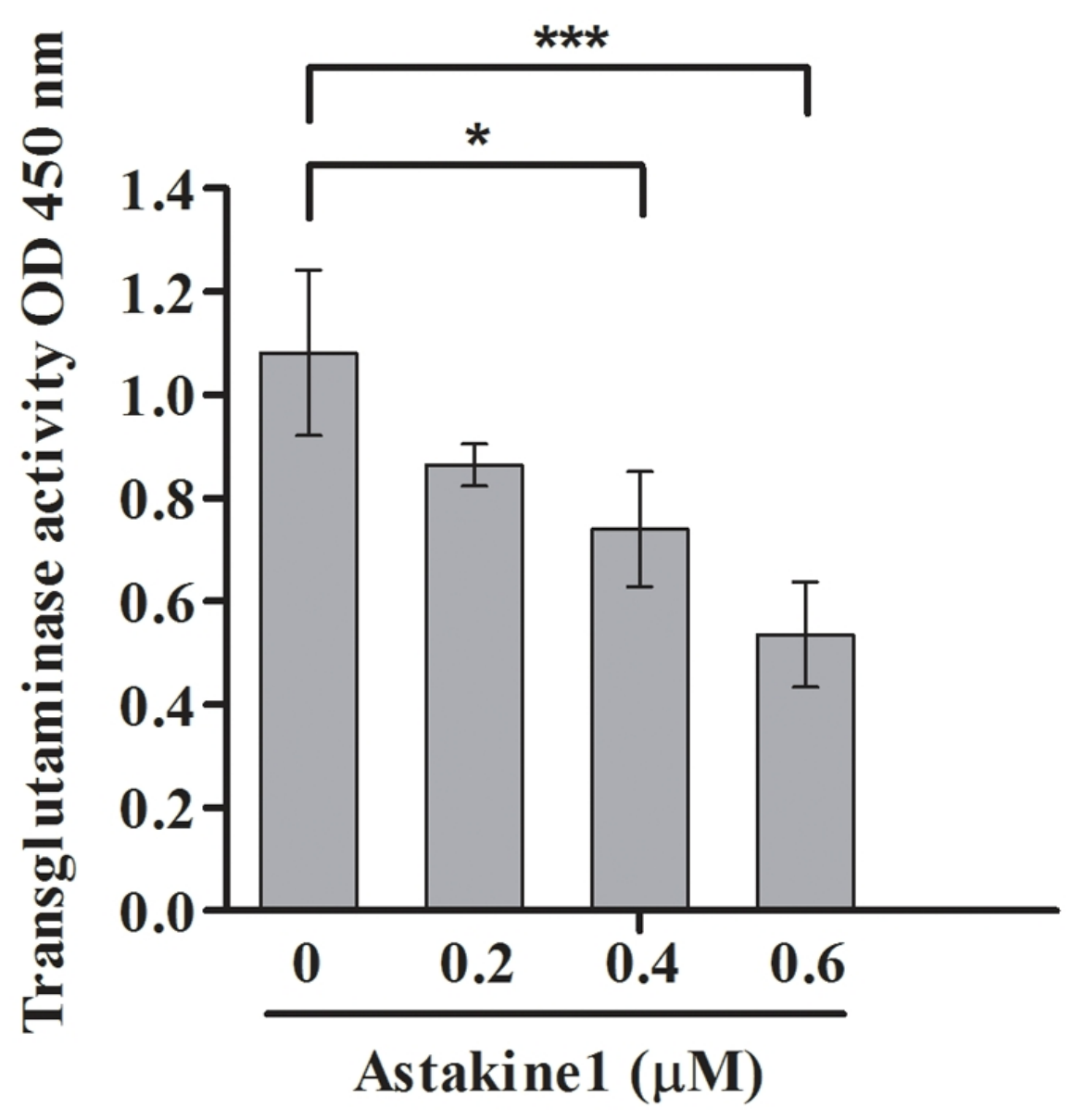




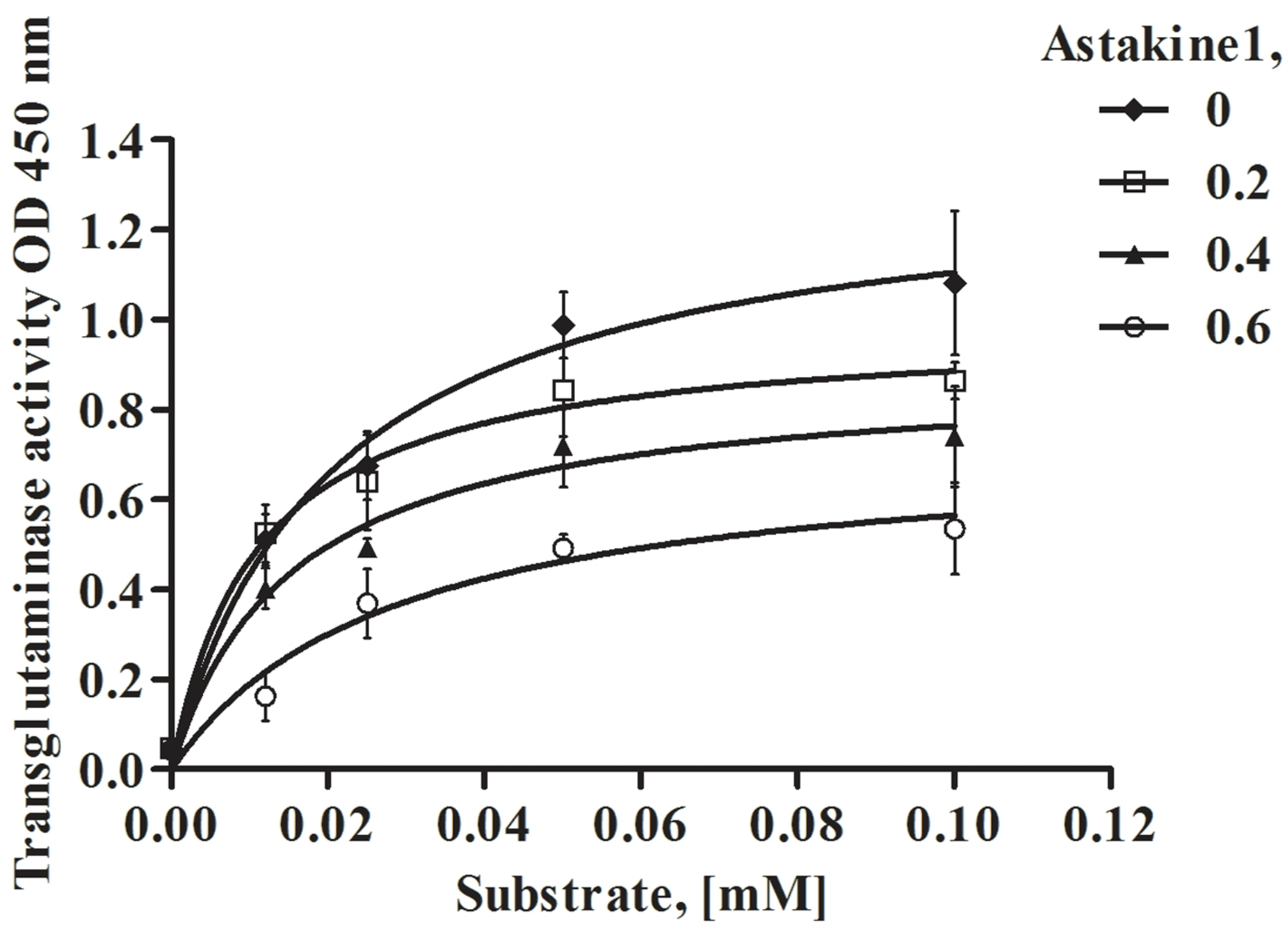


(kDa)

$250-$
$150-$

$75-$

$50-$

CP-depleted plasma

$\mathrm{CP}$

TGase

Astakine1

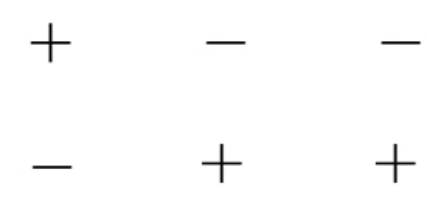

$+\quad+$

$-\quad-\quad+$ 
- The relationship between astakine1 and TGase activity was characterized.

- Astakine1 acts as an inhibitor of TGase activity.

- Astakine1 reduces TGase-mediated crosslinking of the purified clotting protein. 